\title{
ヒドララジンを用いた食品中亜硝酸イオンの ガスクロマトグラフィーによる定量法
}

(昭和 55 年 6 月 3 日受理)

\author{
田中章男* 能勢憲英* 渡辺昭宣*
}

\section{Gas Chromatographic Determination of Nitrite in Foods by Using Hydralazine}

\author{
Akio TanaKa, Norihide Nose \\ and Akinobu WATANABE \\ (Saitama Institute of Public Health: 639-1, Kamiōkubo-higashi, Urawa-shi, Saitama)
}

\begin{abstract}
A simple and practical method for the determination of nitrite in foods is described. It is based on the reaction of nitrite with hydralazine in acidic solution $(\mathrm{pH} 1.0 \sim 3.0)$ at $70^{\circ} \mathrm{C}$ for $10 \mathrm{~min}$ to form tetrazole $[5,1-\alpha]$ phthalazine, a stable compound which can be extracted with toluene and determined quantitatively by means of gas-liquid chromatography with a flame-ionization detector and a column of $3 \%$ OV-225 on Chromosorb W HP; the minimum determinable amount of nitrite-nitrogen was $0.02 \mu \mathrm{g} / \mathrm{ml}$.

A sample was finely chopped and ground in a porcelain pestle and mortar, then 5 $10 \mathrm{~g}$ of the mixture was transferred into a $100 \mathrm{ml}$ volumetric flask by means of $70 \mathrm{ml}$ of hot water (ca. $80^{\circ} \mathrm{C}$ ), and $2.5 \mathrm{ml}$ of $1 \mathrm{~N}$ sodium hydroxide solution and $5 \mathrm{ml}$ of $12 \% \mathrm{zinc}$ sulfate solution were added. The whole was shaken occasionally in a water-bath at $80^{\circ} \mathrm{C}$ for $20 \mathrm{~min}$, then cooled to room temperature, and filtered. (Vegetables and vegetable products were extracted at $80^{\circ} \mathrm{C}$ with occasional shaking for $60 \mathrm{~min}$ without the addition of $1 \mathrm{~N}$ sodium hydroxide solution or $12 \%$ zinc sulfate solution.)

A $20 \mathrm{ml}$ volume of the filtrate was reacted with hydralazine, extracted twice with $5 \mathrm{ml}$ of toluene and then concentrated to $5 \mathrm{ml}$ by blowing dry nitrogen gas at $50^{\circ} \mathrm{C}$. The con. centrated solution was passed through an alumina column to remove interfering substances from foods. Twenty $\mathrm{ml}$ of hexane and $15 \mathrm{ml}$ of acetone were added successively to the column at a rate of $3 \mathrm{ml} / \mathrm{min}$. The acetone eluate was concentrated to $2 \mathrm{ml}$ by blowing dry nitrogen gas at $50^{\circ} \mathrm{C}$. The final solution was injected into the gas chromatograph.

The recovery of nitrite added to various foods ranged from 94.5 to $98.1 \%$ and, the standard deviation for the whole procedure was $1.1 \%$ for 28 determinations. The results of nitrite determination by proposed method were in good agreement with those of the colorimetric method.
\end{abstract}

(Received June 3, 1980)

Key words: ヒドララジン hydraladine; 亜硝酸イオン nitrite ion; ガスクロマトグラフィー gasliquid chromatography; テトラゾロフタラジン tetrazolophthalazine

\section{緒言}

业硝酸塩は食肉および鯨肉製品，魚肉ソーセージ，八 么等の発色剂として広く利用され，その使用基準が食品 衛生法で定められている. 食品中の亜硝酸の定量法とし ては, 亜硝酸を加温抽出し，除タンパクし，そのろ液に ついてジアン゙化反応により比色する方法1) 3)がある. し かし，この方法は抽出操作で得られる試験溶液が食品の

* 埼玉県衛生研究所：浦和市上大久保東 639-1
種類によっては混濁または着色し，場合によっては定量 が困難となることがある．このことから，亜硝酸をガス クロマトグラフィーにより定量する方法を検討した．ガ スクロマトグラフィーによる方法は, 亜硝酸を酸化して, 硝酸としベンゼン4)や，2,4-キシレノール(5)をニトロ化す る方法, 亜硝酸とオルトフェニレンジアミンと反応させ て $1 \mathrm{H}$-ベンゾトリアゾールを生成する方法 ${ }^{8)}$.7)等が報告 されている，乙かし，ニトロ化法は感度は良いが，高濃 
度の硫酸を使用することまた，オルトフェニレンジア ミン法は反応および生成物抽出時でそれぞれの溶液の $\mathrm{pH}$ が異なるため, その都度調製しなければならないな どの問題がある.著者らは, ヒドララジンが亜硝酸と反 応8) 乙定量的に, テトラゾロフタラジンを生成すること より，これを用いてガスクロマトグラフィーにより食品 中の亜硝酸を定量する方法を検討したところ良好な結果 が得られたので報告する。

\section{1. 実験方法}

\section{1 試料}

魚肉ソーセージ, 食肉八ム, サラミソーセージ, たら こ, コーンビーフ (かん詰), ホウレンソウおよびトマト はいずれも市販品を用いた。

\section{2 試薬および装雷}

亚硝酸標準溶液：乾燥した互硝酸ナトリウム（試薬特 級) $0.493 \mathrm{~g}$ を精密にとり蒸留水に溶かして $1000 \mathrm{ml}$ と し, 原液とした. 次に原液 $10 \mathrm{ml}$ をとり, 水を加えて $100 \mathrm{ml}$ としたものよりその $2 \mathrm{ml}$ をとり, 水を加えて全 量を $100 \mathrm{ml}$ とし標準溶液とする. (用時調製). 亜硝酸<smiles>NNc1nncc2ccccc12</smiles>

Hydralazine<smiles>c1ccc2c(c1)cnn1nnnc21</smiles>

Tetrazole $[5,1-\alpha]$ phthalazine
Scheme 1. Formation of tetrazolophthalazine
性窒素標準溶液 $1 \mathrm{ml}=0.2 \mu \mathrm{g} \mathrm{NO}-\mathrm{N}$.

$0.5 \%$ ヒドララジン溶液：ヒドララジン塩酸塩（試薬 特級） $0.5 \mathrm{~g}$ を蒸留水に溶解し $100 \mathrm{ml}$ とした.

活性アルミナ：市販品（酸性, Merck 社製）をそのま ま使用した。

ガスクロマトグラフ用充てん剂：3\% OV-225（クロ モソルブ $\mathrm{W}, \mathrm{HP}, 80 \sim 100 \mathrm{mesh}$, 日本クロマト工業 (株)製）を用いた。

ガスクロマトグラフ：(株)島津製作所製 GC-7AG 型 (FID 検出器付).

\section{3 試験溶液の調製}

細切試料 5〜10 g をビーカーに精科し，これに約 $80^{\circ}$ の温湯を適量加え $100 \mathrm{ml}$ のメスフラスコに移し, 容器 を温湯で数回洗ってフラスコに加える.このときフラス コの液量は約 $70 \mathrm{ml}$ とする.これに $1 \mathrm{~N}$ 水酸化ナトリ

Table 1. Analytical Conditions of Gas-liquid Chromatography

Instrument

Column

Liquid phase

Detector

Detector temperature

Column temperature

Carrier gas
Shimadzu GC-7 AG type

Glass column $1 \mathrm{~m} \times$ $3 \mathrm{~mm}$

OV-225, 3\%

Flame-ionization type $300^{\circ} \mathrm{C}$

$230^{\circ} \mathrm{C}$

$\mathrm{N}_{2}, 2.0 \mathrm{~kg} / \mathrm{cm}^{2}$

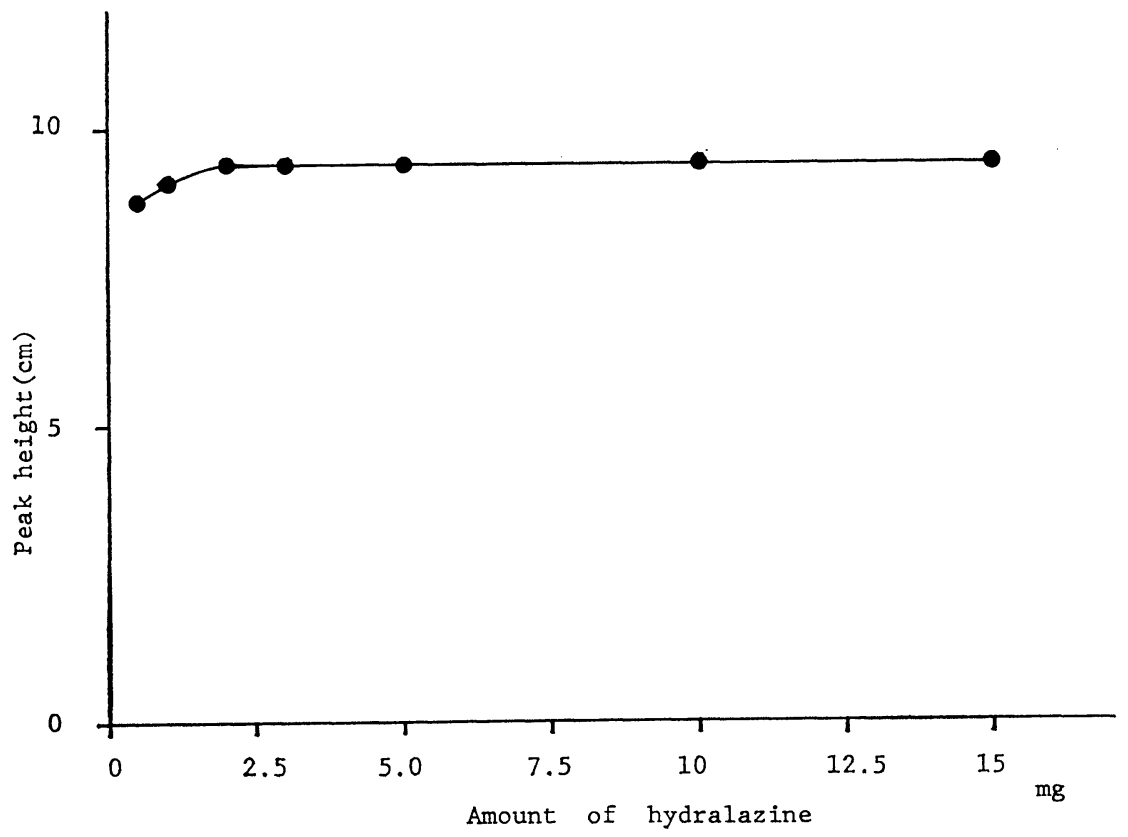

Fig. 1. Effect of amount of hydralazine on the formation of tetrazolophthalazine 


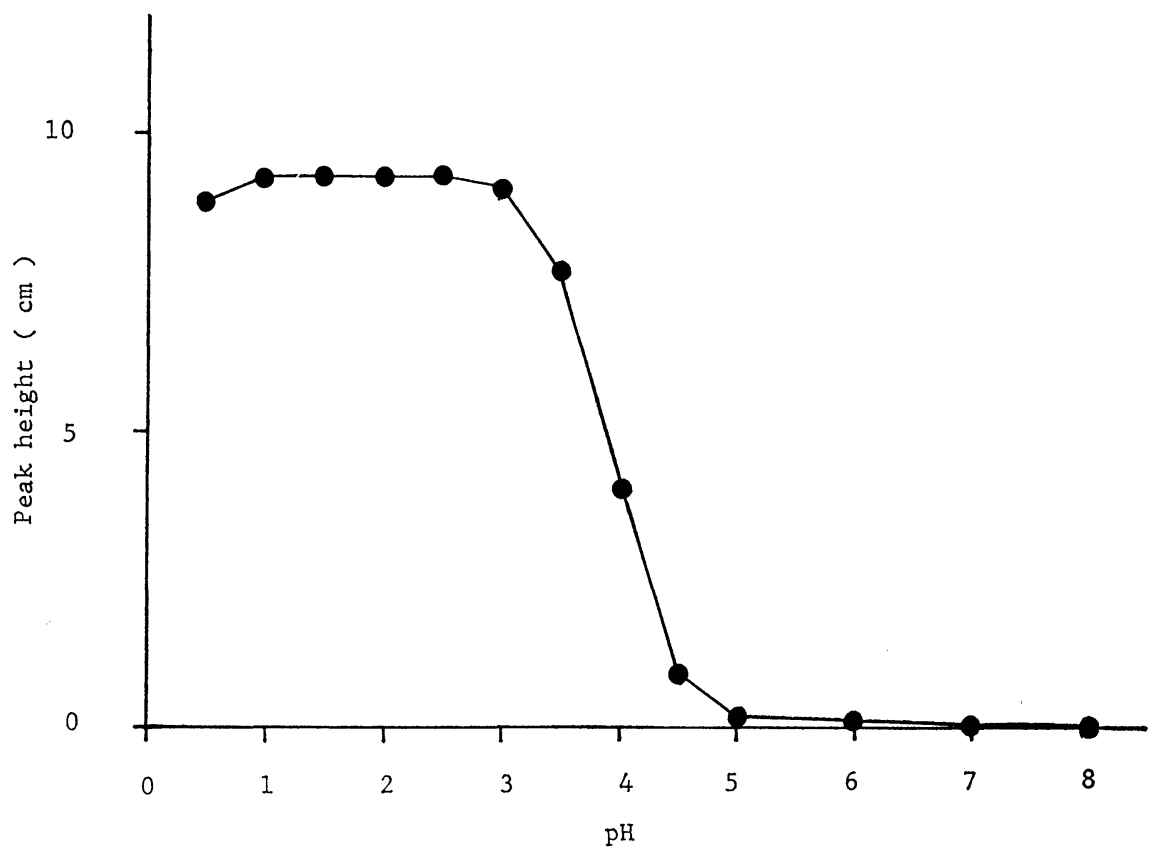

Fig. 2. Effect of $\mathrm{pH}$ on the reaction with nitrite and hydralazine

ウム $2.5 \mathrm{ml}$ を加えてよく振り混ぜた後, $12 \%$ 硫酸亜鉛 溶液 $5 \mathrm{ml}$ を加觉, 時々振り混ぜながら $80^{\circ}$ の水浴中で 20 分間加熱する.（野菜およびその加工品については蒸 留水 $70 \mathrm{ml}$ を加えて $80^{\circ}$ で 60 分間加温抽出した).つ いで泠水中で室温となるまで冷却した後, 蒸留水を加觉 て全量 $100 \mathrm{ml}$ とする. 内容をよく混和した後，ろ過し， 最初のろ液 $10 \mathrm{ml}$ を捨て以後の透明な液を試験溶液と する.

\section{4 テトラソロフタラジンの生成}

ろ液 $20 \mathrm{ml}$ を正確に $50 \mathrm{ml}$ の遠沈管に取り,これに $0.5 \%$ ヒドララジン溶液 $1 \mathrm{ml}$ を加えてよく振り混ぜ, 次に $2 N$ 塩酸 $2 \mathrm{ml}$ を加えてよく振り混ぜた後, 直ち に $70^{\circ}$ の水浴上で 10 分間加熱して反応させる (Scheme 1).

冷却後, 塩化ナトリウム $5 \mathrm{~g}$ を加えてよく混和し, 次 にトルエン $5 \mathrm{ml}$ を加えて 2 分間激しく振とら後, これ を 5 分間 3000 回転で遠心分離した後, トルェン層を 25 $\mathrm{ml}$ の共柽試験管に分取し, 更に先の遠沈管にトルェン $5 \mathrm{ml}$ を加えて再び同様に操作する.ここに得られた前 後の抽出液を合し, これに窒素ガスを通じ，50の水浴 上で $5 \mathrm{ml}$ に濃縮する. 濃縮夜を無水硫酸ナトリウムで 脱水後, あらかじめトルェンで湿潤させたアルミナカラ ム（内径 $1 \mathrm{~cm} \times$ 長さ $30 \mathrm{~cm}$, 下端にガラスウールを軽 く詰めて, $5 \mathrm{~cm}$ の層を作ったもの）に注ぎ, $3 \mathrm{ml} / \mathrm{min}$ の速度でカラム内を流通させる. ついで $n$-ヘキサン 20 $\mathrm{ml}$ を注加し，ヘキサンの流出が終ったならばさらにア セトン $15 \mathrm{ml}$ を加えてテトラゾロフタラジンを溶出さ
せる.この液を $50^{\circ}$ の水浴上で窒素ガスを通じながら $2 \mathrm{ml}$ に濃縮し，これを試験溶液とする。

\section{5 定量操作}

Table 1 に示した測定条件で, 試験溶液 $2 \sim 5 \mu \mathrm{l}$ をガ スクロマトグラフィーに供し，定量を行った。

別に亜硝酸性窒素標準溶液 $2 \sim 20 \mathrm{ml}$ を数個の遠沈管 に取り, 水を加えて全量を $20 \mathrm{ml}$ とした後, 試験溶液の 場合と同様に操作して検量線を作成する. 試験溶液より 得た值を検量線と対比して亜硝酸イオンの量を算出す る.

\section{2. 実験 結 果}

\section{1 ヒドララジンの添加量}

ヒドララジンの添加量を定めるために, 亜硝酸性窒素 標準溶液 $20 \mathrm{ml}$ ずつを遠沈管に取り, $2 N$ 塩酸 $2 \mathrm{ml}$ を 加光次にヒドララジンを蒸留水で $0.5 \sim 15 \mathrm{mg} / \mathrm{ml}$ にし た溶液をそれぞれ $1 \mathrm{ml}$ ずつ加光 1.4 項の方法に従って テトラゾロフタラジンを生成させた. Fig. 1 のようにヒ ドララジン $1 \mathrm{mg}$ 以上で一定量のテトラゾロフタラジン 生成がみられたが，実際に食品を分析するにはこの場合 過㮃と思える $5 \mathrm{mg}$ を適当な添加量とした。 したがっ て $0.5 \%$ ヒドララジン溶液を $1 \mathrm{ml}$ 添加した。

\section{2 テトラソロフタラジンの生成条件}

ヒドララジンと亜硝酸を反応させ，テトラゾロフタラ ジンを生成させる際に塩酸酸性下で行らが，この際反応 液の $\mathrm{pH}$ によっては生成量に変動を生ずることが考え られるため, 生成量がより多く, 一定の值が得られる反 応至適 $\mathrm{pH}$ について検討した. 亜硝酸性窒素標準溶液 


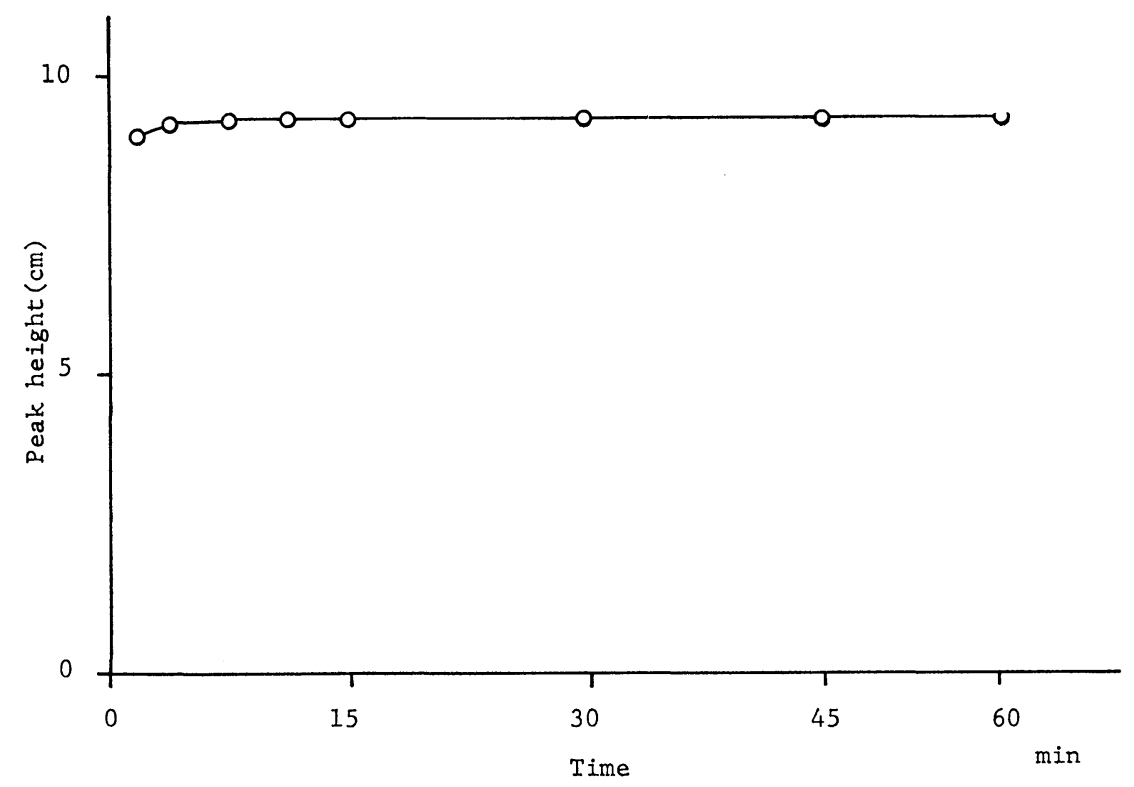

Fig. 3. Time course of formation of tetrazolophthalazine

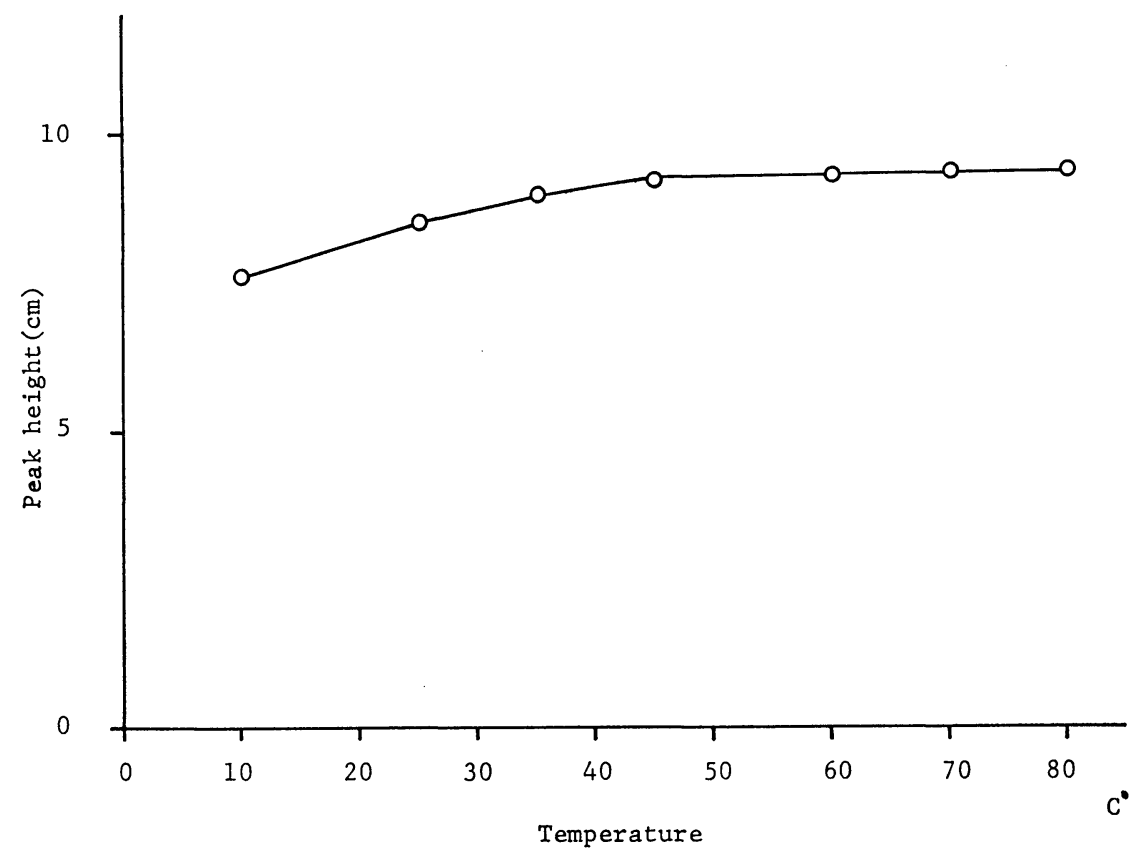

Fig. 4. Effect of temperature on the formation of tetrazolophthalazine

$20 \mathrm{ml}$ をとり $1 N$ 塩酸を用い,それぞれ $\mathrm{pH}$ を $0.5 \sim 8$ の 範囲に調製し， $0.5 \%$ ヒドララジン溶液 $1 \mathrm{ml}$ を加光, $70^{\circ}$ の水浴上で時々かき混ぜながら10分間加熱して反応 を行い, 3.4 項に従って生成したテトラゾロフタラジン を定量した.この結果を Fig. 2 と示したが, pH 1.0〜
3.0 の範囲でほぼー定の生成量を示した.

$\mathrm{pH} 3$ 以上では反応は急激に低下した. $2 N$ 塩酸 $2 \mathrm{ml}$ を加觉ることにより実際の食品の分析の際, $\mathrm{pH}$ が 1.0 〜3.0 の間に達するのでこの量の塩酸を加えることにし た. 


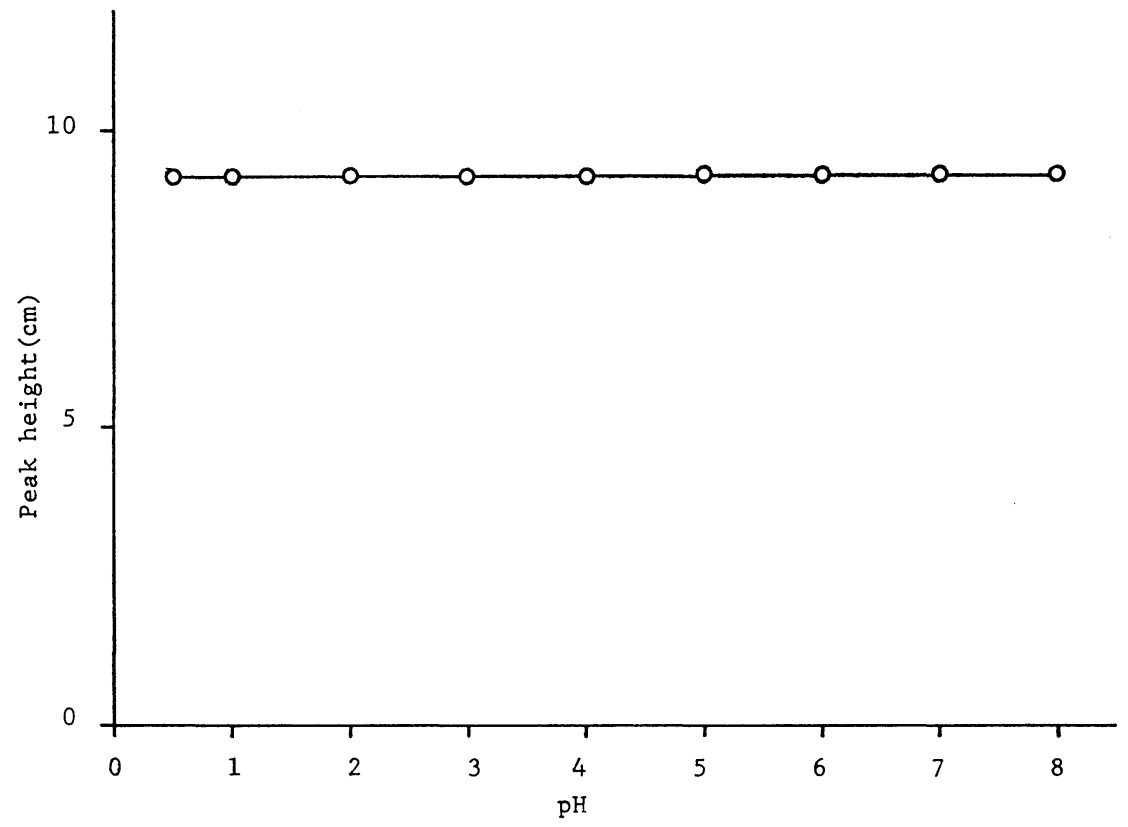

Fig. 5. Effect of $\mathrm{pH}$ on the extraction of tetrazolophthalazine

\section{3 反応時間および温度}

亜硝酸とヒドララジンの反応至適条件を見出すためま ず反応時間の検討を行った。亜硝酸性窒素標準溶液 20 $\mathrm{ml}$ と $0.5 \%$ ヒドララジン溶液 $1 \mathrm{ml}$ を加兄 $70^{\circ}$ で 2 10分間でそれぞれ反応を行った。この結果を Fig. 3 に 示した.

また，反応温度の検討は同様の条件で温度を $10 \sim 80^{\circ}$ までとし，10分間反応を行った．この結果を Fig. 4 に 示した.

Fig. 3, Fig. 4 より反応は短時間で終了し, また温度 も比較的低温でも反応することがわかったが，食品の分 析の場合, 抽出液が混濁した場合反応が進みにくいこと を考慮し反応条件は $70^{\circ}$ で 10 分間加熱とした。

\section{4 抽出至適 $\mathbf{p H}$}

2.2 項によって生成したテトラゾロフタラジンのトル エン抽出時の至適 $\mathrm{pH}$ とテトラゾロフタラジンの抽出率 を求めるため, 亜硝酸性窒素標準溶液 $20 \mathrm{ml}$ を数個の 遠沈管にとり 2.3 項に準じて反応を行った. 反応後, $1 \mathrm{~N}$ 塩酸拉よび $2 \%$ 水酸化ナトリウム溶液で反応液を $\mathrm{pH}$ 0.5 8 の範囲に調製し, 塩化ナトリウム $5 \mathrm{~g}$ を加えた ものにつき, トルェン $5 \mathrm{ml}$ で 2 回抽出した. Fig. 5 によりテトラゾロフタラジンは $\mathrm{pH}$ に関係なく抽出され た. また 2.2 項で述べたテトラゾロフタラジンは生成時 と抽出時の $\mathrm{pH}$ 域が重なっているため, 反応後, $\mathrm{pH} の$ 再調製をする必要はなく，直接抽出することができた。

3.5 抽出溶媒とクリーンアップ

ヒドララジンと亜硝酸により生成したテトラゾロフタ
Table 2. Recovery Tests of Tetrazolophthalazine from Alumina Column Chromatography

\begin{tabular}{c|rrrrr}
$\begin{array}{c}\text { Volume of } \\
\text { acetone (ml) }\end{array}$ & \multicolumn{3}{c}{ Recovery (\%) } & $\begin{array}{c}\text { Average } \\
(\%)\end{array}$ \\
\hline 5 & 90.4 & 90.8 & 91.3 & 92.1 & 91.2 \\
10 & 98.0 & 98.4 & 98.7 & 99.0 & 98.5 \\
15 & 99.2 & 99.7 & 99.8 & 100.0 & 99.7
\end{tabular}

ラジンの抽出溶媒としては酢酸エチル, 酢酸ブチル, ベ ンゼン, トルェン, キシレン, $n$-ヘキサン, シクロヘキ サンについて検討を行ったが, $n$-ヘキサン, シクロへキ サン以外はほぽ 100\%の抽出率であった. 本実験では溶 媒の揮散, 実験操作上の観点等からトルエンを抽出溶媒 とした.

クリーンアップはアルミナカラムの使用により食品中 の色素はほとんど除去され，また魚肉，畜肉製品につい ては, $n$-ヘキサン $20 \mathrm{ml}$ を注加することにより肉製品由 来と思われる油成分は除去された，この段階でのテトラ ゾロフタラジンはアルミナ層 $5 \mathrm{~cm}$ では流出による損失

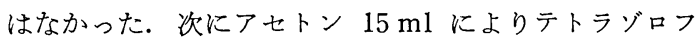
タラジンを完全に流出することができた。この結果は Table 2 に示す.

\section{6 ガスクロマトグラフィーによる定量条件}

ガスクロマトグラフィーの液相として OV-17, SE-30 QF-1，XE-60，OV-225 および PEG-20M などを Table 1 の条件で検討した。この結果, OV-225, PEG- 


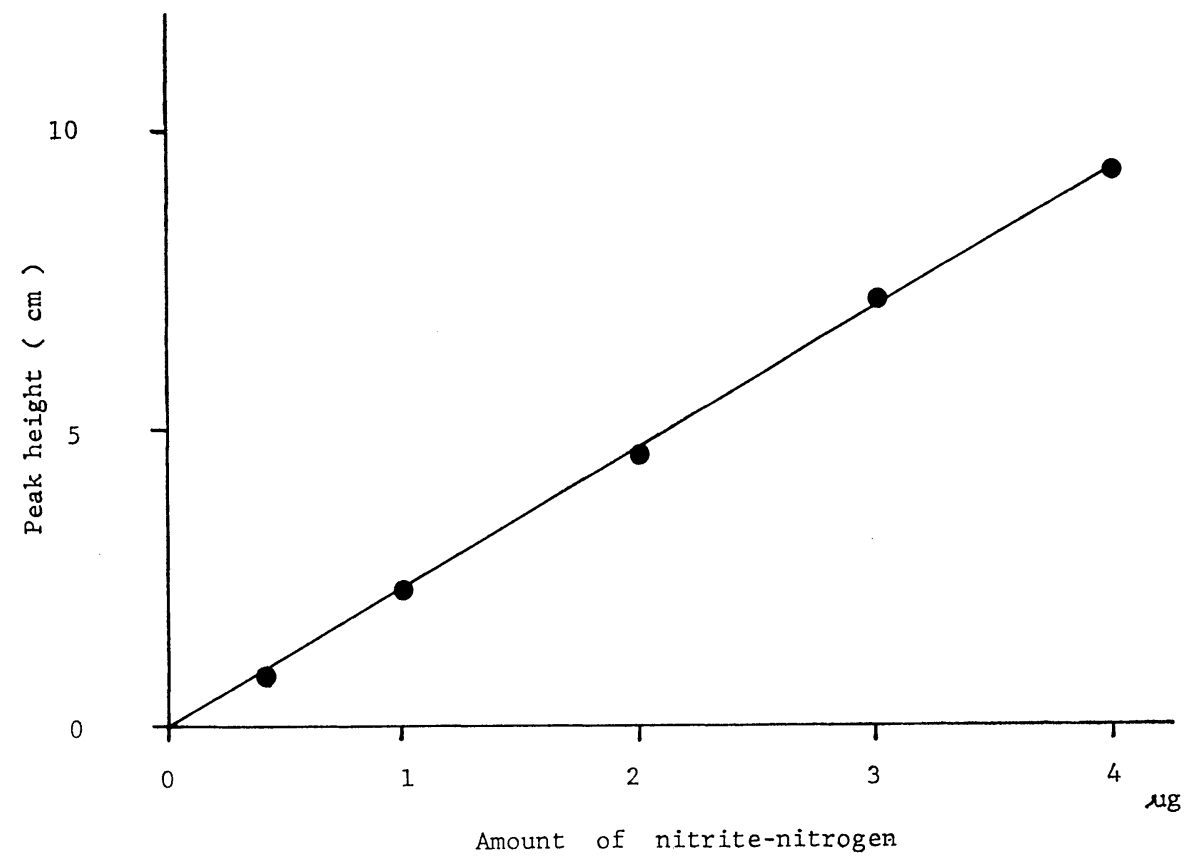

Fig. 6. Calibration curve for nitrite-nitrogen

$20 \mathrm{M}$ 以外のものについては満足なピークは得られず, また OV-225 は PEG-20 M より感度が良好なため, OV-225 を液相として使用することにした．また，カラ ムの長さについても検討を行い, その結果 $1 \mathrm{~m}$ とした. この条件を用い，実際に，Table 4 に示した試料につい て試験を行った.すなわち 1.3 項に準じて試料を調製し, 反応抽出後, ガスクロマトグラフィーを行った結果, い ずれもテトラゾロフタラジンの保持時間 (3.4 分) を奶 害するピークはみられなかった.

また空試験として，ヒドララジンを添加しないものに ついても上記と同様に行ったが，テトラン゙ロフタラジン を妨害するピークは出現しなかった。

また，検量線は亜硝酸性窒素標準溶液を $2 \sim 20 \mathrm{ml}$ と りすでに述べた方法により得られたピーク高を測定し， Fig. 6 に示した検量線を得た.

Fig. 6 より，原点を通り，直線性を示した．また，本 法の定量限界は $20 \mathrm{ng} / \mathrm{ml}$ であった.

\section{7 妨害物質の影響}

試料中に共存すると思われるパラオキシ安息香酸ブチ ル, 安息香酸, ソルビン酸, ブチルヒドロキシフニソー ル、ジブチルヒドロキシトルエンなどの添加物について 検討した. 亜硝酸性窒素標準溶液 $20 \mathrm{ml}$ を各添加物を それぞれ 50 および $100 \mu \mathrm{g}$ を加えて測定した結果，テ トラゾロフタラジンの保持時間に相当する部分には各添 加物のピークは出現せず，測定上影響がないことがわか
Table 3. Influence of Various Food Additives and Nitrate on the Determination of Nitrite by Gas-liquid Chromatography

\begin{tabular}{l|rc} 
Food additives & $\begin{array}{c}\text { Added } \\
\text { amount } \\
\text { to } 4 \mu \mathrm{g} \\
\mathrm{NO}_{2}-\mathrm{N} \\
(\mu \mathrm{g})\end{array}$ & $\begin{array}{c}\text { Recovery } \\
\text { of nitrite } \\
(\%)\end{array}$ \\
\hline Sorbic acid & 50 & 99.9 \\
Benzoic acid & 100 & 99.8 \\
Butyl p-hydroxybenzoate & 50 & 100.1 \\
Butyl hydroxy anisole & 100 & 99.9 \\
& 50 & 99.7 \\
Dibutyl hydroxy toluene & 100 & 99.9 \\
Potassium nitrate & 50 & 99.0 \\
& 100 & 97.2 \\
& 50 & 99.4 \\
& 100 & 98.5 \\
& 50 & 100.0 \\
& 100 & 99.9
\end{tabular}

った. しかし，ブチルヒドロキシアニソール $100 \mu \mathrm{g}$ の 添加によりテトラゾロフタラジンの測定值が若干の低下 を示したまなた妨害物として, 硝酸性窒素の影響を検討 した。硝酸カリウムを用い, $1 \mathrm{ml}$ 中硝酸性窒素 50 およ び $100 \mu \mathrm{g}$ を含む溶液を調製して, 先と同量で同濃度の 
Table 4. Recovery Tests of Nitrite Added to Various Foods

\begin{tabular}{|c|c|c|c|c|c|c|c|}
\hline \multirow{2}{*}{$\frac{\text { Sample }}{\text { Fish sausage }}$} & \multicolumn{2}{|c|}{$\begin{array}{c}\mathrm{NO}_{2}-\mathrm{N} \text { added } \\
(\mu \mathrm{g})\end{array}$} & \multicolumn{2}{|c|}{$\begin{array}{c}\text { Found } \\
(\mu g)\end{array}$} & & \multirow{2}{*}{$\frac{\begin{array}{c}\text { Mean } \\
(\mu \mathrm{g})\end{array}}{0.08}$} & \multirow[t]{2}{*}{$\begin{array}{c}\text { Recovery } \\
(\%)\end{array}$} \\
\hline & 0 & 0.08 & 0.08 & 0.08 & 0.08 & & \\
\hline & 20 & 19.3 & 19.6 & 19.8 & 19.8 & 19.6 & 98.1 \\
\hline \multirow[t]{2}{*}{ Boneless pressed ham } & 0 & 1.9 & 2.0 & 2.2 & 2.2 & 2.1 & \\
\hline & 20 & 21.0 & 21.3 & 21.6 & 21.8 & 21.4 & 96.6 \\
\hline \multirow[t]{2}{*}{ Salami sausage } & 0 & 1.4 & 1.5 & 1.6 & 1.6 & 1.5 & \\
\hline & 20 & 20.1 & 20.5 & 21.0 & 21.1 & 20.7 & 95.9 \\
\hline \multirow[t]{2}{*}{ Pollack roe } & 0 & 1.9 & 2.1 & 2.3 & 2.4 & 2.2 & \\
\hline & 20 & 20.4 & 20.8 & 21.6 & 21.6 & 21.1 & 94.5 \\
\hline \multirow[t]{2}{*}{ Corned beef (Canned) } & 0 & 2.9 & 3.0 & 3.0 & 3.2 & 3.0 & \\
\hline & 20 & 21.4 & 22.4 & 22.5 & 23.0 & 22.3 & 96.6 \\
\hline \multirow[t]{2}{*}{ Spinach } & 0 & 3.1 & 3.1 & 3.1 & 3.2 & 3.1 & \\
\hline & 20 & 21.5 & 21.9 & 22.7 & 22.9 & 22.3 & 95.8 \\
\hline \multirow{2}{*}{ Tomato } & 0 & 0.06 & 0.06 & 0.07 & 0.08 & 0.07 & \\
\hline & 20 & 18.9 & 19.2 & 19.5 & 19.7 & 19.3 & 96.3 \\
\hline Mean value & & & & & & & 96.3 \\
\hline
\end{tabular}

Standard deviation: 1.1

Table 5. Comparison of Colorimetric Method and the Proposed Method for Determination of Nitrite-nitrogen

\begin{tabular}{|c|c|c|}
\hline Sample & $\begin{array}{l}\text { Colorimetric } \\
\text { method } \\
\mathrm{NO}_{2}-\mathrm{N} \\
\text { found } / \mu \mathrm{g}\end{array}$ & $\begin{array}{c}\text { Proposed } \\
\text { method } \\
\mathrm{NO}_{2}-\mathrm{N} \\
\text { found } / \mu \mathrm{g}\end{array}$ \\
\hline \multirow[t]{2}{*}{ Boneless pressed ham } & 1.98 & 2.14 \\
\hline & 3.76 & 3.79 \\
\hline \multirow[t]{2}{*}{ Fish ham } & 4. 10 & 4.18 \\
\hline & 6.34 & 6.29 \\
\hline \multirow[t]{2}{*}{ Pressed ham } & 15.0 & 14.4 \\
\hline & 16.5 & 16.0 \\
\hline \multirow[t]{2}{*}{ Fish sausage } & 0.08 & 0.08 \\
\hline & 0.12 & 0.10 \\
\hline \multirow[t]{2}{*}{ Salami sausage } & 1.59 & 1.53 \\
\hline & 3.50 & 3.20 \\
\hline \multirow[t]{2}{*}{ Pork sausage } & 8.40 & 8.93 \\
\hline & 11.2 & 10.8 \\
\hline
\end{tabular}

亜硝酸性窒素標準液をとり先に述べた方法で測定した. 以上の結果は Table 3 に示した.

また，除タンパク剂として $12 \%$ 硫酸亜鉛溶液を用い たが，テトラゾロフタラジン生成反応上の影響は全くな かった.

\section{8 食品中亜硝酸の定量と測定精度}

各種食品中の 亜硝酸の 定量と 添加回収実験を $1.3 \sim$ 1.4 項に準じて行った結果は Table 4 に示す.
なお，測定值は 4 回の繰り返し定量を行った值であ る.この結果, 平均回収率は $96.3 \%$ と良好な値が得ら れた。 また，本法による測定值の標準偏差は士1.1\%で あった．本法とジアゾ化3)による測定法を比較するため 比較的着色の少なかった数種の市販加工肉製品をそのま ま用い, 1.3 項の方法に準じて得られた抽出液をジアゾ 化して測定を行い, 本法の 測定結果と比較し, Table 5 に示す。

Table 5 のように, 両法の測定值に大差なくほぼ等し い結果を得た。な技，ジアゾ化法では野菜および着色の 著しい食品については直接比色定量ができなかったの で，本法と蒸留法を比較したが石崎らりの報告にみられ るように，測定值が一定の值を示さず比較はできなかっ た.

\section{4. 結 論}

以上の結果から本法は,

（1）亜硝酸をとドララジンと塩酸酸性で $70^{\circ} ， 10$ 分 間加熱後生成したテトラゾロフタラジンをトルェン抽出 する.

その際，反応時と抽出時の $\mathrm{pH}$ が同じなのでそれぞれ を調製する必要はなく，操作が簡単である。

（2）着色料，天然色素などの夾雑物はアルミナカラ ムクロマトグラフィーで生成したテトラン゙ロフタラジン と分離することができる.

（3）ガスクロマトグラフィーにより，亜硝酸をテト ラゾロフタラジンとして測定する際, ソルビン酸, 安息 香酸, パラオキシ安息香酸ブチル，ブチルヒドロキシア ニソール，ジブチルヒドロキシトルエンは妨害ピークと 
して出現せず，かつ再現性の良い測定值が得られた。 た，硝酸塩，除タンパク剂の硫酸亜鉛はテトラゾロフタ ラジン生成に影響を与えなかった。

この結果, 本法はジアゾ化比色法と比べてみても測定 值はほぼ一致し食品中の亜硝酸イオンの日常試験法とし て十分実用に供し得る方法と考えられる.

本報告の要旨は, 日本食品衛生学会第39回学術講演会 (1980 年 5 月, 東京) において発表した.

終りに，本実験に際し，試料の提供をいただいた日本 チバガイギー(株) に深謝致します。

文献

1) 西村雅吉, 松永勝彦, 金沢秀郎: 分析化学, 18, 1372 1376 (1969).

2) 菅野三郎, 和田 裕, 中岡正吉, 長谷川由紀子:
食衛誌. 7, 72 75 (1966).

3）日本薬学会編：“衛生試験法注解” p. 311 (1980) 金原出版.

4) Wu, W.S., Peter, W.S.: J. Assoc. Offic. Anal. Chem., 60, 1137 1141 (1977).

5) Toyoda, M., Suzuki, H., Ito, Y., Iwaida, M.: ibid., 61, 508 512 (1978).

6) 秋庭正典, 桐栄恭二, 下石靖昭: 分析化学, 22 , 924 926 (1973).

7) 石崎睦雄, 小山田則孝, 上野清一, 片岡不士雄, 村山りつ子, 久保田かほる, 勝村 繁: 食衛誌. 17, 428〜433 (1976).

8) Darey, J., Ringier, B. H.: Helv. Chemica Acta., 34, 195 (1951). 